\title{
접착제를 사용한 CFRP와 강재 이음부의 강도 해석 Strength Analysis of Joint Between Steel Plate and CFRP Laminated Splice Plates Patched by Adhesive
}

\author{
박대용 Park, Dae-Yong* · 이상열 Lee, Sang-Youl**† · 장석윤 Chang, Suk-Yoon*** \\ (Received March 13, 2011 ; Revised April 28, 2011 ; Accepted May 17, 2011)
}

\begin{abstract}
This paper presents the stress distribution of the damaged butt joint of steel plate using CFRP laminates when the flange in tension zone of steel box girder is welded by butt welding. When CFRP sheets are patched on tension flange of steel-box girder, the stress distribution of a vertical and normal direction on damaged welding part is shown as parameters such as a variation of the thickness of adhesive, the overlap length with steel, and the modulus of elasticity of CFRP sheets. For the study, we wrote the computer program using the EAS(Enhanced assumed strain) finite element method for plane strain that has a very fast convergency and exact stress for distorted shape.
\end{abstract}

요 지

본 연구에서는 강재가 맞대기 이음으로 연결될 경우 CFRP(Carbon Fiber Reinforced Plastic) 쉬트(sheet)를 맞대기 이 음부에 접착할 경우 강재 및 CFRP 쉬트에 발생하는 응력을 해석하였다. CFRP 쉬트로 보강한 경우 접착제의 두께, 강재와의 접착 길이, CFRP 강도 변화를 매개변수로 사용하여 이 매개변수에 변화에 따른 이음부의 응력분포를 분 석하였다. 또한 $\mathrm{CFRP}$ 를 여러 층으로 접착할 경우 각 층의 강도를 다르게 변화시켜 맞대기 이음부에 유리한 응력분 포를 나타내는 $\mathrm{CFRP}$ 의 강도를 제시하였다. 본 연구를 위해 빠른 수렴성을 가지며 왜곡된 요소형상에서도 정확한 응력결과를 보이는 강화변형률장(Enhanced Assumed Strain Field)을 사용한 평면변형률 유한요소에 대한 프로그램을 작성하였다.

Key Words: Butt joint(맞대기 이음부), Enhanced Assumed Strain(강화변형률장), CFRP

\section{1. 서 론}

현재 토목 및 건축 분야의 콘크리트 및 강구조물의 손 상부위를 보수·보강을 위해 CFRP 쉬트(sheet)가 많이 사용되고 있다(Soutis 등, 1999; Hu 등, 2000; Rajan 등, 2001). 그러나 본 연구에서는 이러한 보수·보강의 차원 이 아닌 강구조물의 강재의 맞대기 이음부를 기존의 용접형식이 아닌 CFRP 연결판을 접착제를 사용하여 접착시키는 새로운 연결부 형식을 제시하고자 한다.

이렇게 형성된 연결부는 기존의 용접에 의한 맞대기 이음부에 발생하는 용접부의 취약점을 원천 봉쇄할 수 있다. 따라서 본 연구에서는 이러한 연결부에서 발생 하는 강재와 $\mathrm{CFRP}$ 연결판 및 접착제의 응력을 분석하 고자 한다.

CFRP 연결판을 강재에 접착하여 형성된 연결부의 강도에 영향을 미칠 수 있는 접착제의 두께, 강재와의 접착 길이, CFRP 강도 변화를 매개변수로 사용하여 이
매개변수에 변화에 따른 연결부의 응력분포를 분석하 였다. 또한 $\mathrm{CFRP}$ 를 여러 층으로 접착할 경우 각 층의 강도를 다르게 변화시켜 맞대기 이음부에 유리한 응력 분포를 나타내는 CFRP의 강도를 제시하였다.

본 연구에서 사용한 CFRP 연결판은 섬유는 탄소 섬 유(Carbon Fiber)를 사용하고 매트릭스(Matrix) 혹은 레 진(Resin)은 에폭시(Epoxy)를 사용한 것이다. 이 CFRP 연결판은 섬유를 유리섬유(Glass fiber)나 폴리아라미드 섬유(Polyaramid fiber)를 사용한 것 보다 인장 및 압축 강도와 피로 특성이 뛰어나며 비강성 및 비강도가 우 수하다. 또한 CFRP 연결판을 붙이기 위한 접착제 (adhesive)는 에폭시 본드를 사용하였다. CFRP를 사용 한 연결부의 해석을 위해 빠른 수렴성을 가지며 왜곡 된 요소형상에서도 정확한 응력결과를 보이는 Simo와 Rafai(1990)가 최초로 제안한 강화변형률장(Enhanced Assumed Strain Field)을 사용한 평면변형률 유한요소 프로그램을 작성하였다.

* 정회원 - 대림산업 기술연구소 특수교량팀 과장

**† 정회원·안동대학교 토목공학과 조교수, 교신저자(1sy@andong.ac.kr)

*** 정회원 - 서울시립대학교 토목공학과 명예교수 / (주)이산 상임고문 


\section{EAS 유한요소법}

본 연구에서 최근 Simo \& Rifai(1990)가 제안한 EAS 유한요소법은 강화변형률장(Enhanced Assumed Strain Field)을 사용함으로써 유한요소 해석시 발생하는 왜곡 된 요소 형상이나 찌그러진 요소 형상에 대해 변위와 응력에 대해 정확한 결과, 잠김현상 제거 및 빠른 수 렴성의 장점을 가지고 있다. 따라서 본 연구에서 해석 하고자 하는 강재의 용접부분에 손상이 발생할 경우 $\mathrm{FRP}$ 재료를 사용하여 보강하고자하는 경우 EAS 유한요 소법에 의한 해석을 적용함으로써 정확한 변위 및 응 력 결과를 얻을 수 있다.

\section{1 변분법}

$\mathrm{EAS}$ 방법은 식 (1)과 같이 변형률에 대해 적합 변형 률장 $\left(\epsilon^{c}\right)$ 과 강화 변형률장 $(\tilde{\epsilon})$ 으로 나눌 수 있으며 $\mathrm{Hu}-$ Washizu의 변분 원리에 기초하여 식 (2)와 같은 범함수 로 표현할 수 있다.

$$
\begin{aligned}
& \epsilon=\epsilon^{c}+\tilde{\epsilon}=B u+\tilde{\epsilon} \\
& \Pi_{E A S}(u, \tilde{\epsilon}, \sigma)= \\
& \int_{A}\left[\frac{1}{2}(B u+\tilde{\epsilon}) C(B u+\tilde{\epsilon})-\sigma^{T} \tilde{\epsilon}\right] d A \\
& -\int_{A} u^{T} \bar{b} d A-\int_{L_{\sigma}} u^{T} t d L-\int_{L_{u}} t^{T}(u-\bar{u}) d L
\end{aligned}
$$

여기서 $B$ 는 적합 변형률-변위 관계 행렬, $u$ 는 변 위, $\tilde{\epsilon}$ 은 강화 변형률, $\sigma$ 는 응력, $C$ 는 재료상수 행렬, $\bar{b}$ 는 체적력, $\bar{t}$ 는 표면력, $\bar{u}$ 는 변위에 대해 규정된 경계조건이다.

식 (2)에서 경계조건 및 하중에 대한 부분을 제거한 범함수를 정류 포텐샬 에너지 이론으로부터 1차 변분 을 수행하면 다음과 같은 3 개의 독립된 식 $(3 \mathrm{a}, \mathrm{b}, \mathrm{c})$ 을 얻을 수 있다.

$$
\begin{aligned}
& \int_{A} \delta u^{T} B^{T}[C(B u+\tilde{\epsilon})] d A=0 \\
& \int_{A} \delta \sigma^{T} \tilde{\epsilon} d A=0 \\
& \int_{A} \delta \tilde{\epsilon}^{T}[C(B u+\tilde{\epsilon})-\sigma] d A=0
\end{aligned}
$$

\section{1 변위장}

Fig. 1은 등매개변수 4절점 평면변형률 요소의 전체 좌표계상의 변위장을 나타낸 것이며 전체좌표계상의 요소의 좌표는 식 (4)와 같이 나타낼 수 있으며 이에 대한 가정된 변위는 식 (5)와 같다.

$$
\begin{aligned}
& {\left[\begin{array}{l}
x \\
y
\end{array}\right]=\sum_{i=1}^{4} N_{i}(x, y)\left[\begin{array}{l}
x_{i} \\
y_{i}
\end{array}\right]} \\
& u=[u v]^{T}, u=\sum_{i=1}^{4} N_{i} d_{i}
\end{aligned}
$$

여기서 $N_{i}(x, y)$ 는 전체좌표계상의 등매개변수 4절 점 요소에 대한 형상함수이고 $d_{i}$ 는 전체좌표계상에서 절점당 변위벡터이다.

\section{2 변형률-변위 관계}

\subsection{1 적합 변형률장 (Compatible strain field)}

식 (1)에서 전체좌표계에 대한 적합변형률 $\left(\epsilon^{c}\right)$ 과 변 위와의 관계는 식 (6)과 같다.

$$
\epsilon^{c}=\left[\begin{array}{c}
\epsilon_{x x} \\
\epsilon_{y y} \\
\gamma_{x y}
\end{array}\right]=\left[\begin{array}{c}
\partial u / \partial x \\
\partial v / \partial y \\
\partial u / \partial y+\partial v / \partial x
\end{array}\right]=B u
$$

식 (6)을 자연좌표계상의 형상함수를 사용하여 표현 하면 식 (7)과 같다.

$$
\epsilon^{c}=B u=\sum_{i=1}^{4} J^{1}\left[\begin{array}{c}
\frac{\partial N_{i}(\xi, \eta)}{\partial \xi} \\
\frac{\partial N_{i}(\xi, \eta)}{\partial \eta}
\end{array}\right] d_{i}
$$

여기서 $N_{i}(\xi, \eta)$ 는 자연좌표계상의 4절점 요소의 형 상함수이며 식 (8)과 같다.

$$
N_{i}(\xi, \eta)=\frac{1}{4}\left(1+\xi \xi_{i}\right)\left(1+\eta \eta_{i}\right) \quad i=1 \sim 4
$$

여기서 $\xi, n$ 는 자연자표계이며 $\xi_{i}, \eta_{i}$ 는 자연좌표계 상의 각 절점의 좌표 값으로 +1 또는 -1 의 값을 가진 다.

\subsection{2 강화변형률장 (Enhanced assumed strain} field)

강화 변형률은 이에 상응하는 가상의 변위벡터 $a$ 와 연계되며 $\alpha$ 에 대해 7 개의 매개변수를 사용한 Andelfinger와 Ramm(1993)이 제안한 자연좌표계상의 형 상함수 $\left(M_{\xi}\right)$ 를 사용하여 식 (9)와 같이 나타낼 수 있다.

$$
\tilde{\epsilon}=\widetilde{B} \alpha=\sum_{i=1}^{7} \frac{\operatorname{det} J_{0}}{\operatorname{det} J} T_{0}^{-T} M_{\xi} \alpha_{i}
$$

여기서 $M_{\xi}$ 및 $T_{0}$ 는 각각 식 (10)과 식 (11)로 표 현된다.

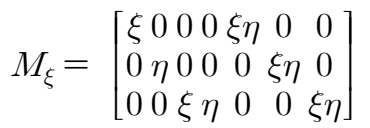

$$
\begin{aligned}
& T_{0}=\left[\begin{array}{ccc}
J_{11_{0}}^{2} & J_{21_{0}}^{2} & 2 J_{11_{0}} J_{21_{0}} \\
J_{12_{0}}^{2} & J_{22_{0}}^{2} & 2 J_{12_{0}} J_{22_{0}} \\
J_{11_{0}} J_{12_{0}} & J_{21_{0}} J_{22_{0}} & J_{11_{0}} J_{22_{0}}+J_{21_{0}} J_{12_{0}}
\end{array}\right]
\end{aligned}
$$


여기서 $\operatorname{det} J$ 는 식 (7)의 Jacobian 행렬의 determinant이고 $\operatorname{det} J_{0}$ 는 자연좌표계상에서의 원 점 $(\xi=\eta=0)$ 에서의 determinant이다. 또한 $J_{i j_{0}}$ 는 원점에서의 Jacobian 행렬 $J_{0}$ 의 요소들이다. 이렇 게 자연좌표계상의 원점에서 Jacobian 행렬을 구 하는 이유는 강화 변형률에 의해 원하지 않는 변 형에너지를 야기하지 않도록 하기 위함이며 요소 가 찌그러진 경우에 조각시험(Patch test) 통과를 보장받기 위함이다(Simo \& Rifai, 1990).

\section{3 응력-변형률 관계}

본 연구에서 강재의 용접부를 FRP 재료를 사용하여 보강하는데 있어 FRP재료는 직교이방성 재료 특성을 가지며 이에 대한 재료축 상에서의 응력과 적합 변형 률과의 관계는 식 (12)와 같다.

$\left[\begin{array}{l}\sigma_{11} \\ \sigma_{22} \\ \sigma_{12}\end{array}\right]=\left[\begin{array}{ccc}C_{11} & C_{12} & 0 \\ C_{12} & C_{22} & 0 \\ 0 & 0 & C_{66}\end{array}\right]\left[\begin{array}{l}\epsilon_{11} \\ \epsilon_{22} \\ \epsilon_{12}\end{array}\right]=C \epsilon$

여기서 $C_{i j}(i, j=1,2,6)$ 를 직교이방성의 평면변 형률에 대해 표현하면 식 (13)과 같다.

$$
\begin{aligned}
C_{11} & =\frac{E_{1}\left(1-\nu_{12}\right)}{\left(1+\nu_{12}\right)\left(1-\nu_{12}-\nu_{21}\right)} \\
C_{22} & =\frac{E_{2}\left(1-\nu_{21}\right)}{\left(1+\nu_{21}\left(1-\nu_{12}-\nu_{21}\right)\right.} \\
C_{12} & =\frac{\nu_{21} E_{1}}{\left(1-\nu_{12}\right)} C_{11} \\
C_{66} & =G_{12}
\end{aligned}
$$

여기서 $E_{1}, E_{2}$ 는 각각 재료축 1,2 방향 탄성계수이 고 $G_{12}$ 는 전단탄성계수이며 $\nu_{12}, \nu_{21}$ 은 포아송 비이 다.

본 연구에서는 구조축과 재료축이 같은 방향이므로 식 (12)와 식 (13)의 재료축에 대한 응력과 변형률 및 탄성계수 행렬은 구조축에 대한 표현과 같다.

\section{4 요소강성}

요소의 최종 강성행렬은 정적응축기법을 사용하여 강화변형률의 매개변수 $a$ 를 강성행렬에서 제거함으로 써 얻어질 수 있으며 식 (14)와 같다.

$$
\begin{aligned}
& {\left[\begin{array}{ll}
K_{C C} & K_{C N} \\
K_{C N}^{T} & K_{N N}
\end{array}\right]^{e}\left[\begin{array}{l}
u \\
\alpha
\end{array}\right]^{e}=\left[\begin{array}{l}
F \\
0
\end{array}\right]} \\
& K^{e}=K_{C C}-K_{C N} K_{N N}^{-1} K_{C N}^{T}
\end{aligned}
$$

여기서, $F$ 는 절점당 가해진 하중 벡터이며 $K_{C C}, K_{C N}, K_{N N}$ 은 식 (15)와 같다.

$$
\begin{aligned}
K_{C C} & =\int_{A} B^{T} C B d A \\
K_{C N} & =\int_{A} B^{T} C \widetilde{B} d A \\
K_{N N} & =\int_{A} \widetilde{B^{T}} C \widetilde{B} d A
\end{aligned}
$$

여기서, $K_{C C}, K_{C N}, K_{N N}$ 에 대해 모두 $2 \times 2$ 가우스 적분법을 사용하였다.

\section{5 응력회복(Stress Recovery)}

본 연구에서는 EAS 요소에 대한 응력을 얻기 위해 응력회복 과정을 거치게 되며 Simo와 Rafai(1990)이 제 시한 최소자승법(Least-square method)을 적용하였다. 이 방법에 있어서 먼저 식 (3b)의 응력과 강화 변형률과의 직교성을 만족시키기 위해 식 (10)의 강화 변형률에 대 해 가정한 형상함수와 독립된 응력에 관한 형상함수를 가정하여야 한다. 따라서 본 연구에서는 응력에 관한 형상함수 $\left(P_{\xi}\right)$ 를 식 $(10)$ 과 독립된 식 (16)과 같이 가정 하였다(Simo \& Rifai, 1993).

$$
P_{\xi}=\left[\begin{array}{lllll}
1 & 0 & \eta & 0 & 0 \\
0 & 1 & 0 & 0 & \xi \\
0 & 0 & 1 & 0 & 0
\end{array}\right]
$$

$\mathrm{EAS}$ 요소에 대한 최소자승법에 의한 응력회복과정 을 요약하면 식 (17)과 같으며 이는 Hellinger-Reissner 변분법을 사용한 HR 요소(Pian \& Chen, 1983)의 수식 화 과정과 같다.

$$
\begin{aligned}
\sigma & =P \beta=T_{0} P_{\xi} \beta \\
H & =\int_{A} P^{T} C^{-1} P d A \\
G & =\int_{A} P^{T} B d A \\
\sigma & =P H^{-1} G u
\end{aligned}
$$

여기서 $B$ 는 식 (7)에서 얻어지는 적합 변형률-변위 관계 행렬이며 또한 $C^{-1}$ 는 식 (12)에서 얻어지는 재 료상수행렬이고 $u$ 는 변위벡터이다. 식 (17)에 대한 적 분은 역시 $2 \times 2$ 가우스 적분법을 적용하였다.

이렇게 얻어진 식 (17)은 가우스 적분점에서 발생하 는 응력이며 4절점 요소의 각 절점에 대한 응력으로 치환하기 위해 외삽법(Extrapolation)을 사용하였다. 가 우스 적분점에서의 응력 $\left(\sigma_{1 \sim 4}\right)$ 을 절점 응력 $\left(\sigma_{A \sim D}\right)$ 으 로 치환하는 방법은 식 (18)과 같다.

$$
\left[\begin{array}{l}
\sigma_{A} \\
\sigma_{B} \\
\sigma_{C} \\
\sigma_{D}
\end{array}\right]=\left[\begin{array}{cccc}
1+\frac{\sqrt{3}}{2} & -\frac{1}{2} & 1-\frac{\sqrt{3}}{2} & -\frac{1}{2} \\
-\frac{1}{2} & 1+\frac{\sqrt{3}}{2} & -\frac{1}{2} & 1-\frac{\sqrt{3}}{2} \\
1-\frac{\sqrt{3}}{2} & -\frac{1}{2} & 1+\frac{\sqrt{3}}{2} & 1-\frac{\sqrt{3}}{2} \\
-\frac{1}{2} & 1-\frac{\sqrt{3}}{2} & -\frac{1}{2} & 1+\frac{\sqrt{3}}{2}
\end{array}\right]\left[\begin{array}{c}
\sigma_{1} \\
\sigma_{2} \\
\sigma_{3} \\
\sigma_{4}
\end{array}\right]
$$




\section{3. 해석 예 및 결과분석}

\section{1 해석모델}

본 연구에서는 CFRP 연결판로 강재를 연결한 연결 부의 강도에 영향을 미칠 수 있는 접착제의 두께 $\left(t_{a}\right)$, 강재와의 접착 길이 $\left(L_{a}\right), \mathrm{CFRP}$ 강도 변화를 매개변수 로 사용하였으며 이 매개변수에 대한 것은 Fig. 1에 나 타내었다.

또한 Fig. 1에서는 유한요소해석을 위한 경계조건 및 하중조건, 모델링 형상을 나타내었다. 기하하적 형상이 대칭이므로 전체 연결부의 $1 / 4$ 만 해석하였으며 경계조 건은 이에 맞게 설정하였다. 또한 하중조건은 오른쪽 단에 모재인 강재의 허용응력 근처의 값이 발생하는 하중을 재하하였다. 사용된 강재는 SM 490이며 두께는 $15 \mathrm{~mm}$ 이고 이 때의 허용응력은 $186.3 \mathrm{MPa}$ 이다(도로교 설계기준, 2003).

Fig. 1에서 빗금친 부분은 강재가 맞대기 이음되는 부분은 접착제를 주입한 것이며 이렇게 하는 이유는 접착제를 주입하지 않으면 $\mathrm{CFRP}$ 연결판에 매우 큰 응 력이 집중되므로 접착제를 주입하여 응력집중을 완화 할 수 있기 때문이다. 유한요소해석을 위해 필요한 물 성치는 Table 1에 나타내었다(ASM International, 1987). 표 2는 해석에 사용된 재료의 인장강도를 나타내었으 며 강재는 SM 490 강재의 항복응력값이다.

Table 1 해석에 사용된 재료 물성치

\begin{tabular}{ccccc}
\hline Material & $E_{x}(G P a)$ & $E_{y}(G P a)$ & $G_{x y}(G P a)$ & $\mathrm{v}_{x y}$ \\
\hline Steel & 210 & 210 & 80.77 & 0.3 \\
Adhesive & 3.4 & 3.4 & 1.26 & 0.35 \\
CFRP & 161 & 10 & 6 & 0.5 \\
\hline
\end{tabular}

Table 2 해석에 사용된 재료의 인장강도 $(\mathrm{MPa})$

\begin{tabular}{cccc}
\hline Material & Steel & Adhesive & CFRP \\
\hline Strength $(M P a)$ & 313.8 & $55 \sim 130$ & $1200 \sim 2250$ \\
\hline
\end{tabular}

\section{2 예비해석 및 해석 매개변수 선정}

Fig. 1과 같은 해석모델에서 접착제와 강재의 접촉 면 및 접착제와 CFRP 접촉면의 응력분포를 먼저 살펴 보았다.

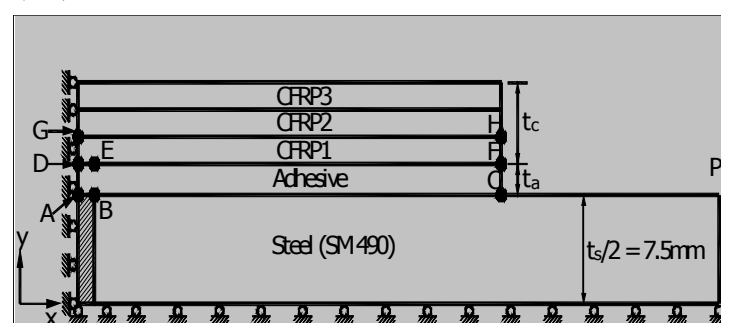

Fig. 1 맞대기 이음부 $1 / 4$ 해석모델
이러한 예비해석을 통해 맞대기 이음부의 응력에 크 게 영향을 미치는 여러 가지 해석변수들을 선정하고자 한다.

먼저 접착제 두께 $\left(t_{a}\right)$ 는 $1.0 \mathrm{~mm}$ 로 설정하였고 CFRP 두께 $\left(t_{c}\right)$ 는 3 개의 층으로 나누었으며 총 두께는 $0.25 t_{s}$ 이고 3 층 모두 같은 탄성계수를 가진 $\mathrm{CFRP}$ 를 사용하 였으며 물성치는 Table 1에 나타내었다. 이렇게 3 개 층 으로 나눈 이유는 일반적으로 CFRP 연결판의 두께는 매우 얇게 만들어지며 설계를 만족하기 위한 두께를 얻기 위해서는 여러 층으로 형성하여 접착시켜야 하기 때문이다. 이렇게 여러 층으로 분리되는 경우 CFRP의 각 층은 접착제를 사용하여 적층형태로 형성된다.

접착길이 $\left(L_{a}\right)$ 는 $4 t_{s}$ 이고 전체길이 $(L)$ 는 $10 t_{s}$ 로 설정 하였다. 이 때 $\mathrm{A} \sim \mathrm{C}$ 및 $\mathrm{D} \sim \mathrm{F}$ 와 $\mathrm{G} \sim \mathrm{H}$ 에서 발생하는 평균응력(Von-Mises stress)을 Fig. 2에 나타내었다.

Table 2 에서 점 $\mathrm{B}, \mathrm{C}, \mathrm{D}, \mathrm{E}$ 에서 응력이 크게 집중됨 을 알 수 있다. 특히 C, E점들은 표 2에 나타나있는 접착제의 최대 인장강도 값 보다 약간 낮은 수준이다. 본 연구에서는 $\mathrm{B}, \mathrm{C}, \mathrm{D}, \mathrm{E}$ 점들의 응력집중을 감소시키 기 위해 예비해석으로 여러 가지 매개변수들을 조정해 본 결과 접착제 두께 $\left(t_{a}\right)$, 접착길이 $\left(L_{a}\right), \mathrm{CFRP}$ 탄성계 수의 영향이 가장 크게 나타남을 알 수 있었다. 따라 서 이러한 매개변수들의 영향을 분석하고자 한다.

\section{3 강재와의 접착길이의 영향}

Fig. 1 에서 강재와의 접착길이 $\left(L_{a}\right)$ 변화에 따른 점 $\mathrm{B}, \mathrm{C}, \mathrm{D}, \mathrm{E}$ 에서의 평균응력(Von-Mises stress)을 Fig. 3 에 나타내었다. 이 때 접착길이 $L_{a}$ 는 $2 t_{s} \sim 8 t_{s}$ 로 변 화시켰으며 $t_{c}$ 는 $0.25 t_{s}$ 이고 3 개층으로 나누었다. 접착 제의 두께 $\left(t_{a}\right)$ 는 $1.0 \mathrm{~mm}$ 로 고정하였다. 사용된 물성치 는 표 1 에 나타나있다.

Fig. 3에서 점 $\mathrm{B}, \mathrm{C}, \mathrm{D}, \mathrm{E}$ 에서 평균응력은 $L_{c}$ 가 $5 t_{s}$ 이상부터는 응력의 변화가 거의 나타나지 않음을 볼 수 있다. 점 $\mathrm{B}$ 에서의 응력의 감소가 뚜렷한데 $L_{a}$ 가 2 $t_{s}$ 일 때와 $5 t_{s}$ 일 때를 비교해보면 약 $15 \%$ 감소하였다. 또한 점 $\mathrm{D}, \mathrm{E}$ 에서는 응력이 증가하는 것으로 나오지만 그 증가율은 크지 않다.

접착제의 접착길이 $\left(L_{a}\right)$ 는 강재두께 $\left(t_{s}\right)$ 의 약 5 배 이 상부터는 응력감소에 영향을 주지 못한다. 따라서 설 계자는 적절한 접착길이를 선택하여 재료의 낭비를 막 을 수 있다. 


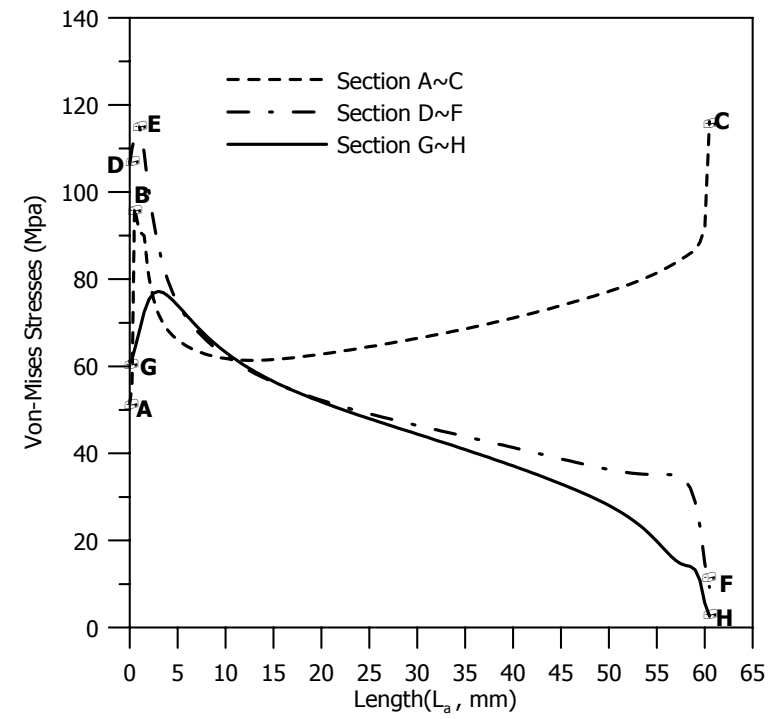

Fig. $2 \mathrm{~A} \sim \mathrm{C}, \mathrm{D} \sim \mathrm{F}, \mathrm{G} \sim \mathrm{H}$ 에서 발생하는 평균응력

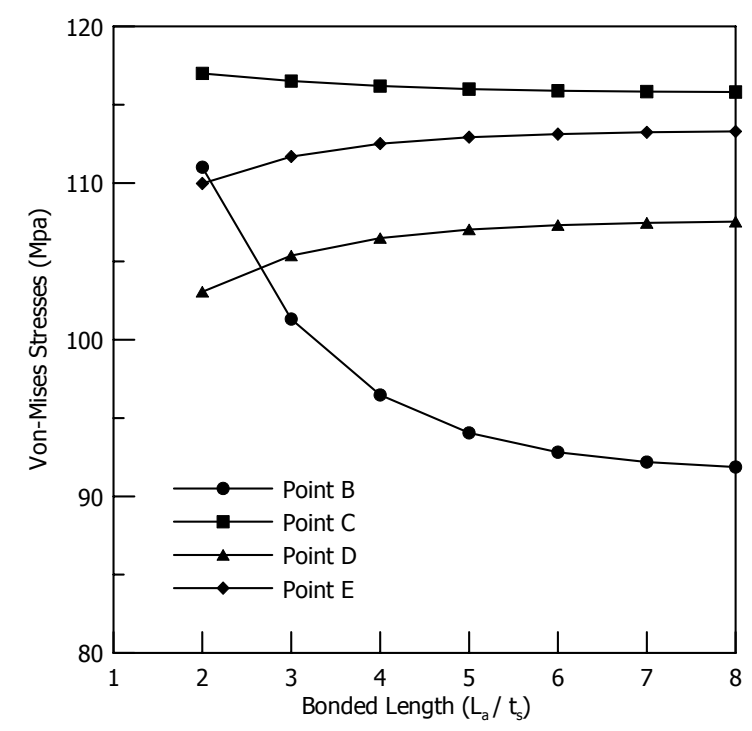

Fig. 3 접착 길이 $\left(L_{a}\right)$ 변화에 따른 점 $\mathrm{B}, \mathrm{C}, \mathrm{D}$, $\mathrm{E}$ 에서의 평균응력(Von-Mises stress)

\section{4 접착제의 두께 $\left(t_{a}\right)$ 의 영향}

Fig. 2에 나타난 바와 같이 응력이 집중되는 점들 $(\mathrm{B}$, $\mathrm{C}, \mathrm{D}, \mathrm{E})$ 의 응력을 감소시키기 위해 본 절에서는 접착 제의 두께 변화에 따른 영향을 살펴보았으며 그 결과 를 Fig. 4에 제시하였다. 이 때 사용된 기하형상 및 재 료물성치는 Fig. 1 과 표 1 나타내었으며 접착제의 두께 변화는 강재와 CFRP 연결판 사이에 삽입되는 접착제 만의 두께 변화를 의미한다. 즉 3 층짜리 $\mathrm{CFRP}$ 연결판 들 사이에 삽입되는 접착제 두께는 변화시키지 않고 $0.25 \mathrm{~mm}$ 로 고정하였다. 또한 접착길이 $\left(L_{a}\right)$ 는 Fig. 3 에서 알 수 있듯이 응력이 거의 변화가 없는 $5 t_{s}$ 로 설정하 였다.

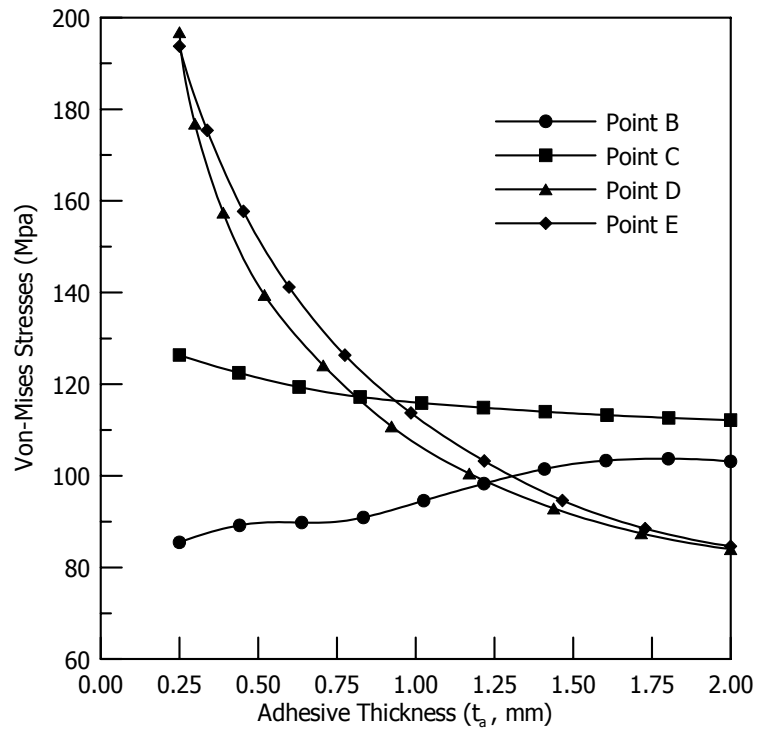

Fig. 4 접착제 두께 $\left(t_{a}\right)$ 변화에 따른 점 $\mathrm{B}, \mathrm{C}, \mathrm{D}$, $\mathrm{E}$ 에서의 평균응력(Von-Mises stress)

Fig. 4에서 접착제의 두께 $\left(t_{a}\right)$ 가 두꺼워 짐에 따라 점 $\mathrm{D}, \mathrm{E}$ 에서 평균응력이 매우 크게 감소하였다. 즉 점 $\mathrm{D}, \mathrm{E}$ 에서 $0.25 \mathrm{~mm}$ 와 $2.00 \mathrm{~mm}$ 를 비교해보면 약 $56 \%$ 감 소하였다. 또한 접착제 두께가 $1.50 \mathrm{~mm}$ 이상이 되면서 부터는 응력감소률이 현저히 떨어짐을 알 수 있다. 일 반적인 에폭시(Epoxy) 접착제의 강도는 Table 2에 나 타나있듯이 $55 \sim 130 \mathrm{MPa}$ 정도이다.

따라서 $\mathrm{CFRP}$ 연결판을 사용하여 강재의 맞대기 이 음부를 설계하는 경우 강재와 CFRP 연결판사이에 삽 입되는 접착제 두께에 따라 매우 큰 영향을 받으므로 응력집중을 완화하기 위해서는 적절한 접착제 두께를 선정해야하며 접착제의 강도를 최대한 큰 것을 사용하 여야 한다.

\subsection{CFRP 강도 변화의 영향}

본 절에서는 $\mathrm{CFRP}$ 가 여러 층으로 형성되는 경우 각 층의 $\mathrm{CFRP}$ 의 재료 물성치를 조절하여 응력집중을 완 화하는 방법을 제시하고자 한다. 즉, Fig. 1에서와 같 이 만약 3 개의 층으로 나누어 $\mathrm{CFRP}$ 연결판을 적층하 는 경우 CFRP1, CFRP2, CFRP3의 재료 물성치를 각각 다르게 사용할 수 있다. 서론에 언급했듯이 CFRP는 에 폭시(Epoxy) 매트릭스와 탄소섬유(Carbon fiber)로 만들 어지는데 탄소섬유의 양을 조절함으로써 여러 가지 다 른 물성치를 갖는 $\mathrm{CFRP}$ 를 만들 수 있다. 이렇게 만들 어진 $\mathrm{CFRP}$ 의 일반적인 섬유방향 탄성계수는 $120 \sim 250$ $G P a$ 이고 인장강도는 $1200 \sim 2250 \mathrm{MPa}$ 이다(Teng, 2002). $\mathrm{CFRP}$ 는 일반적인 강재와 비교시강종과 두께에 따라 다르지만 약 3 4배 큰 인장강도를 가진다.

따라서 3 개의 층으로 구성된 $\mathrm{CFRP}$ 의 각각의 재료 물성치는 Table 3 에 나타내었다. 이때 CFRP 연결판을 
적층하기 위한 접착제 두께는 $0.25 \mathrm{~mm}$ 이고 강재와 $\mathrm{CFRP}$ 사이에 삽입되는 접착제 두께는 $1.5 \mathrm{~mm}$ 이다. 접 착길이 $\left(L_{a}\right)$ 는 $75 \mathrm{~mm}\left(=5 t_{s}\right)$ 로 고정하였고 $\mathrm{CFRP}$ 의 각층 의 두께는 $1.25 \mathrm{~mm}\left(=0.25 t_{s} / 3\right)$ 이다.

Table 4는 각층의 탄성계수가 같은 경우와 각층의 탄성계수가 다른 경우에 점 $\mathrm{B}, \mathrm{C}, \mathrm{D}, \mathrm{E}$ 에서의 평균응 력값을 나타낸 것이다. Table 4에서 CASE 1은 CFRP1, $\mathrm{CFRP} 2, \mathrm{CFRP} 3$ 층의 탄성계수가 Table 2에서 가장 낮 은 탄성계수 값으로 모두 같은 경우이며 CASE 2는 CFRP1, CFRP2, CFRP3 층의 탄성계수가 Table 2에서 가장 높은 탄성계수 값으로 모두 같은 경우이며 CASE 3 은 $\mathrm{CFRP} 1, \mathrm{CFRP} 2, \mathrm{CFRP} 3$ 순서로 탄성계수가 점점 작아지는 경우이며 CASE 4는 CFRP1, CFRP2, CFRP3 순서로 탄성계수가 점점 커지는 경우이다.

Table 4에서 알 수 있듯이 CASE 4의 경우에 다른 $\mathrm{CASE}$ 와 비교시 점 $\mathrm{B}, \mathrm{C}$ 는 응력변화가 거의 없으며 점 $\mathrm{D}, \mathrm{E}$ 에서 평균응력이 가장 작게 나타남을 알 수 있다.

대체적으로 CASE 4의 경우가 응력 집중이 적게 나 타났으며 CFRP 강도를 가장 아래층을 저강도로 시작 하여 점점 고강도로 배치를 하게 되면 응력집중을 감 소시키는데 유리하다.

Table 3 3층으로 구성된 CFRP 각층의 재료물성치

\begin{tabular}{ccccc}
\hline Material & $E_{x}(G P a)$ & $E_{y}(G P a)$ & $G_{x y}(G P a)$ & $\nu_{x y}$ \\
\hline CFRP1 & 120 & 8 & 6 & 0.25 \\
CFRP2 & 180 & 12 & 9 & 0.25 \\
CFRP3 & 250 & 16.67 & 12.5 & 0.25 \\
\hline
\end{tabular}

\section{4. 결 론}

본 연구에서는 강구조물의 강재 맞대기 이음부를 기 존의 용접형식이 아닌 CFRP 연결판을 접착제를 사용 하여 외부에서 붙이는 새로운 연결부 형식을 제시하였 으며 연결부 강도에 영향을 미칠 수 있는 접착제의 두 께, $\mathrm{CFRP}$ 연결판의 두께, 강재와의 접착 길이, $\mathrm{CFRP}$ 강도 변화를 매개변수로 사용하였다. 연결부의 응력분 포 해석을 위해 빠른 수렴성을 가지며 왜곡된 요소형 상에서도 정확한 응력결과를 보이는 강화변형률장 (Enhanced Assumed Strain Field)을 사용한 평면변형률 유한요소 프로그램을 작성하여 매개변수에 변화에 따 른 연결부의 응력분포를 살펴본 결과는 다음과 같다.

(1) 강재와의 접착 길이변화에 따른 연결부 응력집 중 점에서의 응력변화는 접착길이가 강재두께의 약 5 배 이상부터 응력감소에 영향을 주지 못함을 알 수 있 었다. 따라서 설계자는 적절한 접착길이를 선택하여 재료의 낭비를 막을 수 있다.

(2) 강재와의 접착면에서 접착두께 변화는 응력집중 점에서의 응력감소에 가장 크게 영향을 주는 것을 알
수 있으며 접착제 두께가 $1.5 \mathrm{~mm}$ 이상부터 응력 감소 율은 떨어진다.따라서 CFRP 연결판을 사용하여 강재의 맞대기 이음부를 설계하는 경우 강재와 CFRP 연결판 사이에 삽입되는 접착제 두께에 따라 매우 큰 영향을 받으므로 응력집중을 완화하기 위해서는 적절한 접착 제 두께를 선정해야하며 접착제의 강도를 최대한 큰 것을 사용하여야 한다.

(3) CFRP 연결판의 강도를 모두 같은 것으로 사용하 는 것보다 저강도에서 고강도로 순차적으로 크게 층을 배열하게 되면 좀 더 유리한 응력분포를 기대할 수 있 다.

본 연구결과로부터 CFRP와 강재와의 접착에 대한 가이드라인을 제시할 수 있을 것으로 기대된다. 그러 나 실제 실험을 통하여 본 연구결과를 보다 실제적으 로 검증할 수 있는 후속연구가 필요하다.

Table 4 CFRP 강도변화의 영향(평균응력, Von-Mises, MPa)

\begin{tabular}{ccccc}
\hline Point & B & C & D & E \\
\hline \multirow{2}{*}{ CASE 1 } & 109.69 & 113.16 & 77.82 & 80.27 \\
& $(1.10)$ & $(1.00)$ & $(1.18)$ & $(1.18)$ \\
\hline \multirow{2}{*}{ CASE 2 } & 89.72 & 115.14 & 107.33 & 108.74 \\
& $(0.90)$ & $(1.01)$ & $(1.63)$ & $(1.60)$ \\
\hline \multirow{2}{*}{ CASE 3 } & 97.01 & 114.7 & 123.88 & 125.42 \\
& $(0.97)$ & $(1.01)$ & $(1.88)$ & $(1.84)$ \\
\hline \multirow{2}{*}{ CASE 4 } & 99.79 & 113.33 & 65.83 & 68.16 \\
& $(1.00)$ & $(1.00)$ & $(1.00)$ & $(1.00)$ \\
\hline
\end{tabular}

\section{참고 문헌}

1. 박대용, 장석윤(2010) 강화변형률 솔리드 요소를 사 용한 사각형태 층간분리를 갖는 복합적층판의 탄성 좌굴해석, 한국복합신소재구조학회 논문집,제 1 권 제 2호, pp.1-13.

2. 박대용, 장석윤 (2004) 복합적층 패널로 보강된 단순 지지 판의 좌굴해석, 한국강구조학회논문집, 제 16 권 제5호, pp. 621-628.

3. 박대용, 이상열, 장석윤 (2004) ANS를 갖는 $\mathrm{DKM}$ 요소에 $\mathrm{EAS}$ 를 적용한 새로운 4절점 Mindlin 평판 휨 요소, 대한토목학회논문집, 제 25 권 제 $1 \mathrm{~A}$ 호, pp. 107-115.

4. 장석윤, 임성순, 박대용 (2004) 프리스트레스트 구조 물을 위한 새로운 FRP 텐던용 쐐기형 앵커시스템의 구조거동, 대한토목학회논문집, 제 25 권 제 $1 \mathrm{~A}$ 호, pp. 233-240.

5. 최회권 (2004) 비등방성 적층 구조물의 접착 연결부 응력 분포, 서울시립대학교 석사학위논문.

6. Andelfinger, U. and Ramm, E. (1993) EAS-elements for two-dimensional, three-dimensional, plate and shell structures and their equivalence to HR-elements, Int. J. 
Nume. Meth. Engng. Vol. 36, pp. 1311-1337.

7. Choi, H. K., Chun, K. S., Park, D. Y., Chang, S. Y. (2003) Assessment of stress distribution in adhesively bonded joints, Proceedings of the 7th Korea-Japan Joint Seminar on Steel Bridges, Daejeon, Korea, pp. 191-202.

8. Lee SY and Park DY (2007), Buckling analysis of laminated composite plates containing delaminations using the enhanced assumed strain solid element. Int J Solids Struct, Vol.44, pp. 8006-8027.

9. Simo, J.C. and Rifai, M.S. (1990) A class of mixed assumed strain methods and the method of incompatible modes, Int. J. Nume. Meth. Engng., Vol.29, pp. 1595-1638. 